Article

\title{
The Corporate Sustainability Strategy in Organisations: A Systematic Review and Future Directions
}

\author{
Margarida Rodrigues and Mário Franco *(D) \\ CEFAGE-UBI Research Center, Department of Management and Economics, University of Beira Interior, \\ Estrada do Sineiro, 6200-209 Covilhã, Portugal; mmmrodrigues@sapo.pt \\ * Correspondence: mfranco@ubi.pt
}

Received: 10 October 2019; Accepted: 5 November 2019; Published: 6 November 2019

check for updates

\begin{abstract}
The corporate sustainability strategy in organisations is a current topic and set in Agenda 2030 for sustainability, and so this study aims to map the literature on the subject through a bibliometric analysis. From 97 documents identified and analyzed, the results obtained show the fragmentation and hiatus between the planning of a global strategy and inclusion therein of a sustainable strategy. Furthermore, these results provide the construction of a framework as an auxiliary tool for managers of different organisations to implement a sustainable strategy, this being the main contribution of the study. In addition, the theoretical contribution of this study is to obtain evidence that the resources and market position of organisations is crucial to the successful implementation of this type of strategy, in which the resource-based view and competitive advantage proved to be appropriate to support the same. The contribution to the practice showed the importance of having full involvement and commitment of all stakeholders in this implementation, so that the organisations acquire the so ambitious internal and external legitimacy. Finally, some limitations, indications for future research are draw.
\end{abstract}

Keywords: corporate sustainability; systematic literature review; formulation and implementation; sustainable strategy

\section{Introduction}

Research in the management area has not identified many conceptual differences between the processes of constructing a sustainable management strategy and the traditional strategy. However, this research highlighted some factors and drivers, in the context of sustainability, which impact executives' decision-making process in organisations regarding the type of strategy to adopt and its sustainability [1-4]. It is therefore interesting and topical to address this question as a great many organisations have not yet integrated corporate sustainability in their global management strategy [5]. This means that managers should be directed to construct sustainable business practices, highlighting the formulation and implementation of management processes and systems that include those practices [6].

The concept of strategy has undergone a constant, dynamic evolution since its origin, in the face of phenomena occurring in the business environment, particularly that of globalization. Shrivastava [7] emphasized that strategy is an orientation to define long-term objectives, where crucial programmed and/or plans are chosen to achieve them, in accordance with appropriate allocation of resources. Other authors [8] emphasized the definition of plans and actions necessary to attain defined objectives. Ronda-Pupo and Guerras-Martin [9], in their compilation of the evolution of this concept, also stated that strategy can be seen as a path to cope with the environment, as a vehicle to reach a competitive 
advantage and high organizational performance. Strategy has been studied as a concept implicit to management since the 1950s, always aiming to obtain a competitive advantage [1].

The globalization of business environments, the growing importance of sustainable development in the 21st century and corporate sustainability in its three dimensions (economic, social and environmental), led to researchers and organizational managers in the 1990s being faced with a paradigm of transition regarding strategic management [10]. According to these authors, this transition was already shown in their book in 1996 [11], when stating that "strategic managers" know that most of the decisions they make can potentially affect the natural balance, and here lies the change in thought concerning the relationship between economic activity and sustainability. Stead and Stead [12] also concluded that this thinking is considered critical.

Regarding the phenomenon of globalization, another important concept must also be defined, i.e., sustainable development. Historically, this concept has been addressed from 1945 until today, by various international organisations (www.cebds.org). Conceptually, sustainable development has been relevant in the last decades [5]. The World Economic Commission on Environment and Development [12] defined sustainable development as development that satisfies the needs of the present without jeopardizing the capacity for future generations to also satisfy theirs (here, three basic principles were defined [13]: environmental integrity (related to not harming the natural environment); social equality/equity (equal access to resources and opportunities) and economic prosperity (organisations' productive capacity to provide individuals with a reasonable quality of life).

Based on the definition of universal sustainable development, Carcano [5] argued it is accepted that without corporate support, society will not achieve sustainable development as organisations represent the economy's productive resources [14], and so organisations face this question more and more [5]. Following this line of thought, Stead and Stead [11] introduced the concept of sustainable strategy, which means that strategic management involves developing competitive advantages that allow organisations to capitalize on environmental opportunities and minimize the threats, as the environmental dimension can provide relevant benefits, despite being subject to some criticism. Stead and Stead [10] based themselves on the premises underlying the concept of business strategy, but aiming to give organisations a three-dimensional (economic, social and environmental—triple bottom line), long-term, competitive advantage.

Supported by the above line of thought, market-based theory [15] and resource-based theory [16] provide a suitable theoretical framework for studying sustainability and strategic management (according to the core of these theories, Engert et al. [1] explained how both focus on organisational performance (market-based vision) and resources (resource-based vision) as key factors, which are crucial questions in the formulation, implementation, execution and assessment of either sustainable or traditional strategy.

In this context, recent decades have seen numerous efforts to integrate the legislation associated with corporate sustainability in organisations' management systems [17]. This means that for organisations to contribute to improving global sustainability, they must undertake an internal transition process of adaptation and flexibility, which should involve all stakeholders and be in line with a long-term strategic view [17,18]. Batista and Francisco [19] also showed the importance of organisations adapting their strategies to the triple bottom line, while considering the particularities of the business, organisational culture and their own resources so that sustainable objectives can be fulfilled in practice. In addition, current business models and management systems should direct organisations towards the creation of a competitive advantage supported by the creation of a sustainable added value $[18,20]$.

Corporate sustainability in management originated the identification of some gaps still in need of conceptual and empirical research. Those gaps concern the lack of scientific knowledge about how these two dimensions can be integrated in practical terms in organisations, namely their formulation, implementation and strategic execution [1]. These authors also mentioned the importance of studying the correlation between all the factors affecting integration per se, while Perrott [21] found little 
empirical evidence of the level and impact of organisational commitment in that integration (degree of uncertainty) and the economic impact of integrating sustainability in the strategy.

The pertinence of the subject of this study is the reflection of the gaps and controversy surrounding the topic found in the literature, which suggests the need to elaborate a conceptual review of scientific articles on the formulation and implementation of the sustainability strategy in companies. Baumgartner [22] concluded on the growing search for literature on this topic as well as the absence of studies providing empirical evidence in this domain [23]. For Adiningrum [24], the formulation and implementation of the strategy is a much debated theme, but urgent questions are raised as little attention has been paid to how corporate sustainable strategy should in fact be implemented [23,25], as this is a double challenge (managers and organisation), leading to a high demand for literature on the subject [26]. Calabrese et al. [18] described how it is fundamental to study the different paths to implementing sustainability in firms, and Rok [20] concluded it is crucial for future research to focus on understanding how firms' management processes and systems can include sustainable strategic management, to allow assessment of its contribution to global sustainability.

The aim of this study is therefore to map the literature related to the implementation of corporate sustainable strategy in organisations, through a bibliometric analysis (co-citation network), preceded by content analysis, which was guided by the premises of quality and credibility required by this type of study [27].

After this introduction to the subject of study, the article is structured as follows; bibliometric methodology, discussion of the results and implications for theory and practice and identifying future lines of research in this area.

\section{Methodology}

Aiming to identify the topics most studied in the area of corporate sustainability strategy, a bibliometric analysis was presented preceded by the respective descriptive analysis of the final database [28,29]. Elaboration of a systematic literature review using the bibliometric method (co-citation analysis), means that scientific articles (empirical and reviews) were the unit of analysis, with the bibliometrics grouping them according to similarity of objective and focus [30], besides allowing their descriptive and conceptual standardization [31-33]. Therefore, the subjectivity of this research was overcome through methodological criteria of planning, development and presentation of the results [34].

Table 1 summarizes the items and research criteria used in this study referring to 11 March 2019.

Table 1. Items and search criteria.

\begin{tabular}{cc}
\hline & Items and Search Criteria \\
\hline Items & Criteria \\
Period: & No chronological filter \\
Online databases: & Web of Science (WOS) \\
Key-words: & (Implementation of the sustainability strategy in companies) \\
Systematization by search category: & Management or Business \\
Systematization by document type: & Articles and Review \\
Software used: & Endnote X8 and Microsoft Excel 2016 \\
Language & English \\
Documents identified and analyzed: & 97 \\
\hline
\end{tabular}

After exporting the informative files of the 97 documents obtained in Web of Science (WOS) to the software mentioned above, the results were presented in Section 3. Results and Discussion. The bibliometric analysis presented in the same section was performed using Vosviewer software, which allows identification of the co-citation and cluster network [35-39]. Finally, the cluster content analysis was included, as well as analysis of the total base selected, sequenced holistically [40-42]. 
Of course, other methodologies for conducting a systematic investigation could be used, either quantitative or qualitative, such as a meta-analysis and the use of another software's (e.g., NVIVO, Endnote, Vantage point).

\section{Results and Discussion}

\subsection{Descriptive Analysis}

According to the documents selected in WOS and included in this analysis (97), empirical articles (95) were found to predominate, with only two review articles. The review articles are by Brockhaus, S., Kersten, W. and Knemeyer, A. M. (2013). Where do we go from here? Progressing sustainability implementation efforts across supply chains, published in Journal of Business Logistics, 1st quartile review and with an impact factor of 2.089 and already cited 51 times, and by Fernández, E., Junquera, B. and Ordiz, M. (2003). Organizational culture and human resources in the environmental issue: a review of the literature published in International Journal of Human Resource Management in the 1st quartile (sub-topic of Strategy and Management) and with an impact factor of 0.939 and 103 citations. This means there is a theoretical hiatus regarding implementation of a sustainable strategy in firms, which represents a challenge and involvement for managers (Figure 1). In addition, the 97 documents have a total of 2.410 citations, with the years 2017 (18 documents) and 2018 (18 documents) having most publications, whereas until the date of the research (11 March 2019) only three articles have been published this year.

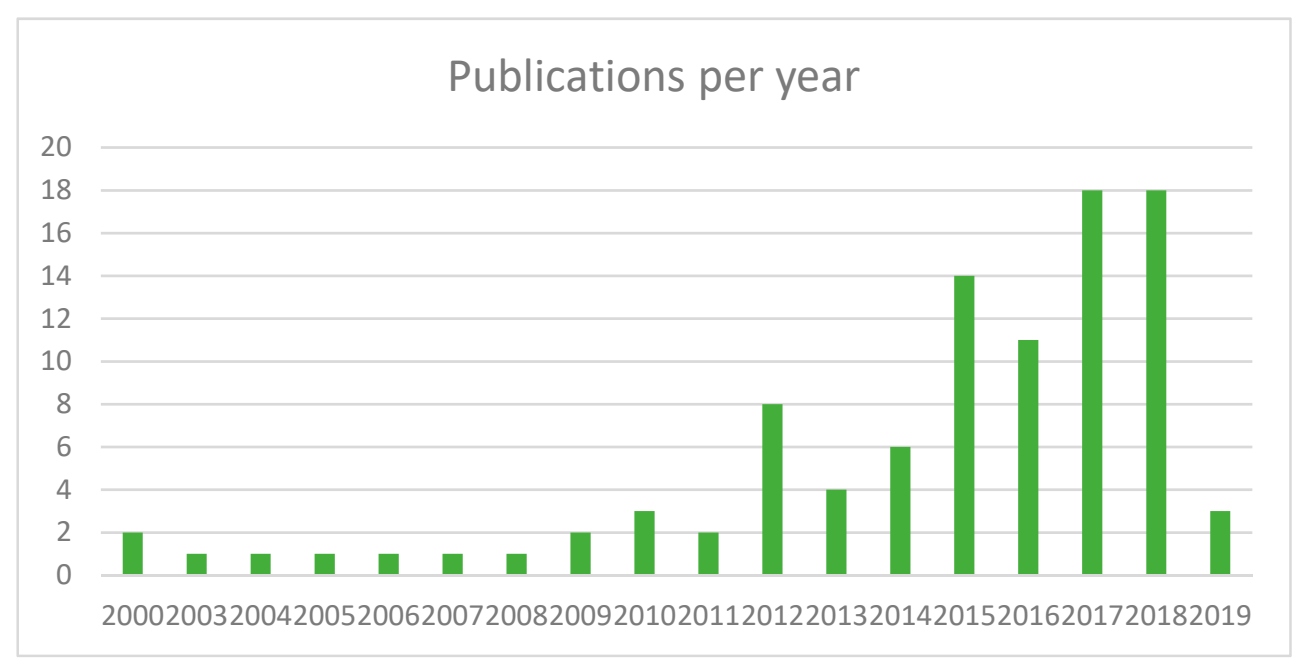

Figure 1. Evolution over time of all publications, adapted from Web of Science (WOS).

It is important to highlight that only in 2000 did the first two publications on this topic emerge, entitled: (1) Effects of "best practices" of environmental management on cost advantage: The role of complementary assets, by Christmann, P. (2000) published in the Academy of Management Journal, 1st quartile review and with an impact factor of 8.548 and 834 citations; (2) Xerox's approach to sustainability by Maslennikova, I., and Foley, D. (2000) in Interfaces journal of the 2nd quartile and with an impact factor of 0.637 and only 57 citations. The last article published in a journal indexed to WOS. Figure 1 shows the evolution of publications from 2000 to 11 March 2019.

Reading of this figure shows that the most productive years in the academic world were 2017 and 2018, as a consequence of approval of Agenda 2030 for sustainable development and the Paris Agreement on climate change, which are international milestones that organisations/companies worldwide cannot avoid. In other words, it became urgent to study the impact these milestones had on the academic world in the years following their approval (2015) and their relationship with tripartite (economic, environmental and social) sustainable organizational strategies in the organizational domain. 
It was also found that the countries contributing most to scientific knowledge on this subject are Spain (13 articles), the United States of America (12 articles), the United Kingdom (11 articles) and Germany (9 articles), representing around $46 \%$ of all publications (97).

Table 2 shows the main journals publishing the 97 documents analyzed.

Table 2. Publications by source titles (Top 10).

\begin{tabular}{ccccc}
\hline Source Title & $\begin{array}{c}\text { No. of } \\
\text { Publications }\end{array}$ & $\begin{array}{c}\text { Impact Factor } \\
\text { (SJR) }\end{array}$ & Quartile & Country \\
\hline Journal of Business Ethics & 8 & 1.276 & Quartile1 & Netherlands \\
Business Strategy and the Environment & 7 & 1.881 & Quartile 1 & USA \\
Amfiteatru Economic & 5 & 0.180 & Quartile3 & Romania \\
Corporate Social Responsibility and & 5 & 1.706 & Quartile 1 & USA \\
Environmental Management & 4 & 0.314 & Quartile3 & UK \\
Benchmarking an International Journal & 4 & 0.867 & Quartile 1 & UK \\
Journal of Manufacturing Technology & 3 & 0.229 & Quartile3 & Romania \\
Management & 3 & 0.634 & Quartile 1 & UK \\
Quality Access to Success & 2 & 2.209 & Quartile 1 & USA \\
Total Quality Management Business & 2 & 1.5001 & Quartile1 & UK \\
Excellence & \multicolumn{3}{c}{ Source: Adapted from WOS } & \\
California Management Review & and SJR Impact Factor & \\
Corporate Governance the International & Journal of Business in Society & & & \\
Others <2 & 97 &
\end{tabular}

Journal of Business Ethics had the greatest number of publications, and the article with the most citations (99) was by Mueller, Dos Santos and Seuring (2009). However, the California Management Review with the highest SJR (Scientific Journal Rankings) only included two publications, with the most cited article (82) being by Perez-Aleman and Sandilands (2008). Nevertheless, the most cited article (834) was not included in the top ten, its journal, the Academy of Management Journal, presenting an SJR (Scientific Journal Rankings) of 8.548.

Table 3 presents the most cited authors in WOS (Web of Science).

Table 3. Top 10 of citations.

\begin{tabular}{|c|c|}
\hline Author/Article/Journal & Total Citations \\
\hline $\begin{array}{l}\text { Christmann, P. (2000). Effects of "best practices" of environmental management on cost advantage: The } \\
\text { role of complementary assets. Academy of Management Journal, 43(4), 663-680. }\end{array}$ & 834 \\
\hline $\begin{array}{l}\text { Golicic, S. L., and Smith, C. D. (2013). A meta-analysis of environmentally sustainable supply chain } \\
\text { management practices and firm performance. Journal of Supply Chain Management, 49(2), 78-95. }\end{array}$ & 167 \\
\hline $\begin{array}{l}\text { Fernández, E., Junquera, B., and Ordiz, M. (2003). Organizational culture and human resources in the } \\
\text { environmental issue: a review of the literature. International Journal of Human Resource Management, 14(4), } \\
634-656 .\end{array}$ & 103 \\
\hline $\begin{array}{l}\text { Mueller, M., Dos Santos, V. G., and Seuring, S. (2009). The contribution of environmental and social } \\
\text { standards towards ensuring legitimacy in supply chain governance. Journal of Business Ethics, 89(4), } \\
509-523 .\end{array}$ & 99 \\
\hline $\begin{array}{l}\text { Baumgartner, R. J. (2014). Managing corporate sustainability and CSR: A conceptual framework } \\
\text { combining values, strategies and instruments contributing to sustainable development. Corporate Social } \\
\text { Responsibility and Environmental Management, 21(5), 258-271. }\end{array}$ & 85 \\
\hline $\begin{array}{l}\text { Perez-Aleman, P., and Sandilands, M. (2008). Building value at the top and the bottom of the global } \\
\text { supply chain: MNC-NGO partnerships. California Management Review, 51(1), 24-49. }\end{array}$ & 82 \\
\hline $\begin{array}{l}\text { Hsieh, Y. C. (2012). Hotel companies' environmental policies and practices: a content analysis of their web } \\
\text { pages. International Journal of Contemporary Hospitality Management, 24(1), 97-121. }\end{array}$ & 63 \\
\hline Maslennikova, I., and Foley, D. (2000). Xerox's approach to sustainability. Interfaces, 30(3), 226-233. & 57 \\
\hline $\begin{array}{l}\text { Olsen, M., and Boxenbaum, E. (2009). Bottom-of-the-pyramid: Organizational barriers to implementation. } \\
\text { California Management Review, 51(4), 100-125. }\end{array}$ & 56 \\
\hline $\begin{array}{l}\text { Duarte, F. (2010). Working with corporate social responsibility in Brazilian companies: The role of } \\
\text { managers' values in the maintenance of CSR cultures. Journal of Business Ethics, 96(3), 355-368. }\end{array}$ & 53 \\
\hline
\end{tabular}


Reading of Table 3 shows once more the article published in the Academy of Management Journal, with an impact factor above 8 , although it was not part of the top 10 journals (Table 1 ). In addition, the most cited articles were from 2000, the first year of publishing articles on the topic studied here.

To sum up, this descriptive analysis shows the trends of the 97 documents selected in WOS, regarding their bibliographic information. However, this should be complemented by a bibliometric analysis using Vosviewer software, as presented in the next section.

\subsection{Bibliometric Analysis}

Exporting the files of the 97 documents forming the final database from Endnote X8 software to Vosviewer software led to obtaining co-citation network outputs. This network (Figure 2) reflected the similarities of the bibliographic references of those documents, i.e., the bibliographic connection was performed [43] and clusters formed to determine the frequency with which two documents were cited [36-39].

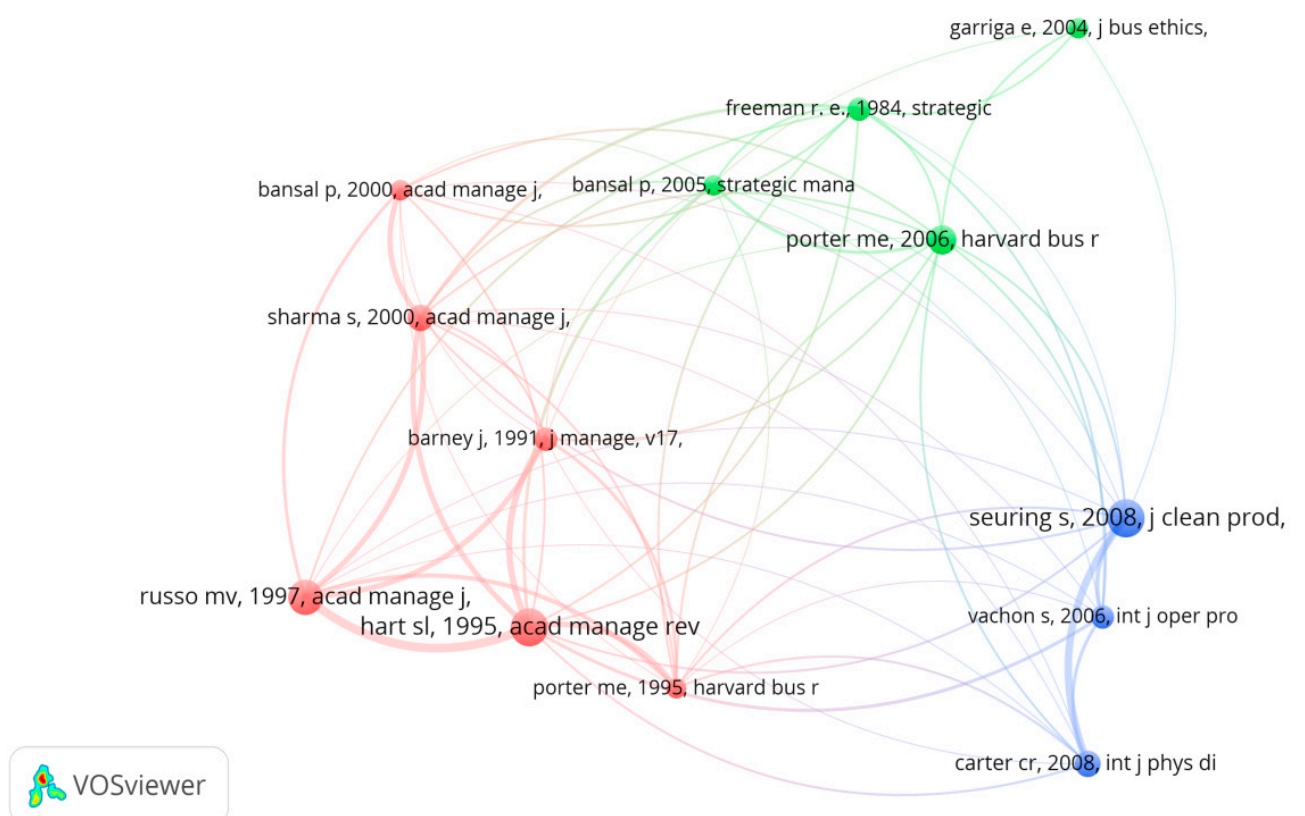

Figure 2. Co-citation network of references.

Three clusters were seen to be obtained with a total of 13 documents. In each cluster, three nodes stand out (larger circles) showing the relative importance of the number of citations of each document, while the distancing (curved lines) of the other documents represents the dimension of the documents' connection in bibliographical terms.

Table 4 below shows the content analysis of the three clusters obtained and then their relationship with all the selected articles (97).

Cluster 1 addressed the sustainable competitive advantage in a close relationship with the consequences of current environmental issues. The authors included in this cluster present various theoretical settings and frameworks to overcome the negative impacts on the environment by organisations/firms. Cluster 2 dealt exclusively with the integration of corporate social responsibility in organizational strategies and its relation with short and long-term competitive advantage. Finally, Cluster 3 addressed sustainability in the field of strategic management of the supply chain. A common flow was perceived in these three clusters in relation to the link between competitive advantage, sustainability and the importance of implementing a sustainable strategy in firms as an integral part of their production chain, of tangible and intangible resources, which it should be possible to assess and monitor so that society in general gives legitimacy to their contribution to improving global sustainability. 
Table 4. Cluster analysis.

\begin{tabular}{|c|c|c|c|}
\hline Author(s)/Year & Co-Citations & Type of Document & Content Analysis \\
\hline \multicolumn{4}{|c|}{ Cluster 1-Environmental Questions and Sustainable Competitive Advantage and Inherent Theoretical Support } \\
\hline Hart (1995) [44] & 13 & Theoretical & $\begin{array}{l}\text { Proposal of a new theory of competitive advantage based on firms' } \\
\text { natural resources to support the strategy of pollution prevention; } \\
\text { Presented various frameworks to apply those strategies, leading } \\
\text { to the generation of a sustainable competitive advantage. }\end{array}$ \\
\hline $\begin{array}{l}\text { Russo and Fouts } \\
\text { (1997) [45] }\end{array}$ & 12 & Empirical/qualitative & $\begin{array}{l}\text { - Supported by the vision based on the firm's resources, they } \\
\text { argued that firms' environmental performance and economic } \\
\text { performance have a positive relationship. }\end{array}$ \\
\hline Sharma (2000) [46] & 9 & Empirical/quantitative & $\begin{array}{l}\text { Studied relations between environmental questions and strategies } \\
\text { for their solution in firms; } \\
\text { Concluded that managers should adapt organisational structure } \\
\text { for this to be an effective situation and should also motivate their } \\
\text { human resources to perceive environmental questions as } \\
\text { an opportunity. }\end{array}$ \\
\hline Barney (1991) [16] & 8 & Empirical/qualitative & $\begin{array}{l}\text { - Examined the relation between firms' resources and sustainable } \\
\text { competitive advantage, using four indicators-value, imitability, } \\
\text { rarity and sustainability; } \\
\text { Considered that managers are fundamental for sustainable } \\
\text { competitive advantage, as firms' resources equipped with } \\
\text { essential competences. }\end{array}$ \\
\hline Bansal (2000) [47] & 7 & Empirical/qualitative & $\begin{array}{l}\text { By studying the motivations and contextual factors that induce } \\
\text { corporate ecological responsibility, they explained that } \\
\text { competitiveness, legitimacy and ecological responsibility are a } \\
\text { consequence of firms' involving factors (e.g., cohesion). }\end{array}$ \\
\hline Porter (1995) [48] & 7 & Empirical/qualitative & $\begin{array}{l}\text { - Firms are in a phase of paradigmatic transition, i.e., they are } \\
\text { simultaneously green and competitive, and have to use all their } \\
\text { resources in an extremely productive and innovative way; } \\
\text { Suggested that environmentalists, regulating entities and firms } \\
\text { should base themselves on logic of integration in relation to the } \\
\text { environment, resource productivity, innovation and } \\
\text { competitiveness as a single element. }\end{array}$ \\
\hline
\end{tabular}

Cluster 2-Corporate Social Responsibility and Competitive Advantage

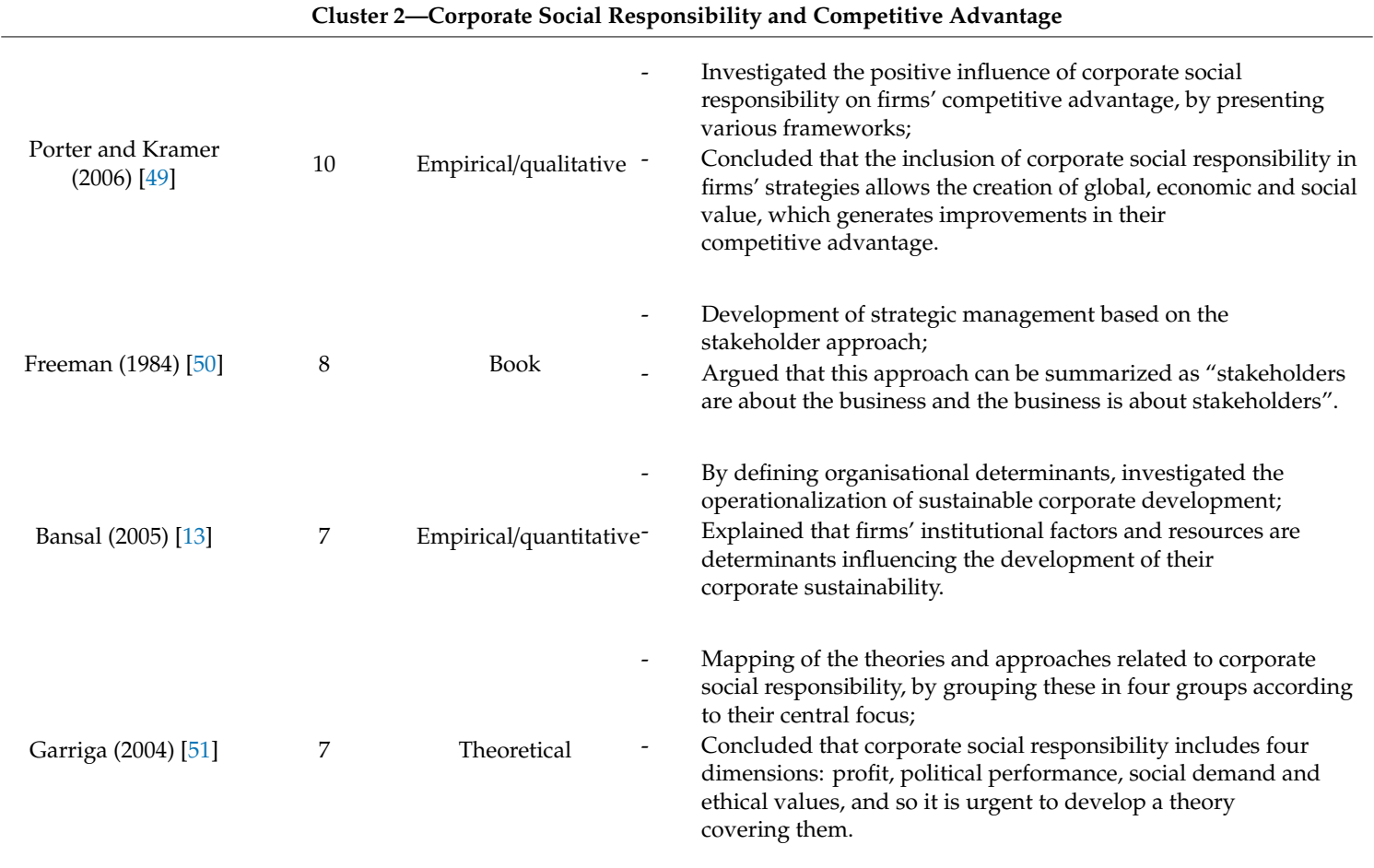


Table 4. Cont.

\begin{tabular}{|c|c|c|c|}
\hline Author(s)/Year & Co-Citations & Type of Document & Content Analysis \\
\hline \multicolumn{4}{|c|}{ Cluster 3-Sustainable Management of the Supply Chain } \\
\hline $\begin{array}{l}\text { Seuring and Müller } \\
\text { (2008) [33] }\end{array}$ & 13 & Theoretical & $\begin{array}{l}\text { Reviewed the literature on sustainable management of the supply } \\
\text { chain, from the supplier and the product perspectives associated } \\
\text { with environmental questions. }\end{array}$ \\
\hline $\begin{array}{l}\text { Carter and Rogers } \\
\text { (2008) [52] }\end{array}$ & 9 & Theoretical & $\begin{array}{l}\text { By developing an intermediate theory of sustainable management } \\
\text { of the supply chain, they understood demonstration of relations } \\
\text { between environmental, social and economic performance within } \\
\text { that chain. }\end{array}$ \\
\hline $\begin{array}{l}\text { Vachon and Klassen } \\
\text { (2006) [53] }\end{array}$ & 8 & Empirical/quantitative & $\begin{array}{l}\text { - Studied the application of green practices in firms' supply chains } \\
\text { in logistic and technological constructs and their relation with } \\
\text { the environment; } \\
\text { Inferred there are positive relations between these constructs and } \\
\text { the environment. }\end{array}$ \\
\hline
\end{tabular}

The topics addressed in these three clusters were the result of a vast amount of literature on corporate sustainability, its integration in organisations' global strategy and implicit associations with their formulation and implementation of a sustainable strategy. Consequently, it is important that the clusters obtained were complemented with content analysis to achieve the characteristics of amplitude, quality and credibility of this systematic literature review [27].

Between 1992 and 1996, there was a significant volume of scientific publications on the dimensions of corporate sustainability, particularly in the Academy Management Review [10]. In 1996 the literature already highlighted criticism regarding practical application of sustainable strategy in organisations, particularly its implementation [10]. Despite its evolution, the concept of sustainable management strategy in the 21st century is still considered incomplete, i.e., it does not provide the incorporation of social performance, but only contemplates environmental and economic performance [10]. Given this gap, the concept of the three dimensions was introduced in 1997. In these circumstances, the model by Porter [54] is incomplete, as it assumes the economy to be a closed system, not including these dimensions. However, in the sustainable management strategy, these dimensions are extremely important and should therefore be included in organisations' value chain [55].

Obviously, underlying this strategy is the concept of corporate sustainability, highlighting some relevant contributions to its definition: satisfying the total needs of organisations' stakeholders, in the present and future [56]; organisations must apply sustainability in its three dimensions, for them to be recognized as contributing to sustainable development ([13]; application of the three dimensions provides unique opportunities for a competitive advantage and organisations' improved reputation [56].

In addition, there is extensive literature clarifying the importance of integrating corporate sustainability in organisations. However, this integration implies: sharing values as a reflection of its three dimensions, without casting doubt on their competitive advantage [57]; stakeholder satisfaction [5]; adoption of a "strategy as a response to environmentalism" [58,59]; this strategy's relationship with those defined by Porter in 1985 [48,60-63] and reassessment of values, of the role of all collaborators and the operationalization of business activities [10].

Consequently, strategic management of corporate sustainability is a response so that there is a return/benefit from organisations' investment in the social and environmental sphere, to mitigate the impacts provoked here by activities [1]. Baumgartner [3], Baumgartner and Ebner [22] and Lozano [64] pointed out that to achieve real progress, corporate sustainability needs to be joined in a holistic perspective, i.e., considering its three dimensions, its impacts and its correlations. If organisations strive to incorporate corporate sustainability in their activities, managers' strategic decisions must take these dimensions into consideration [26]. It is noted that this integration process produces a web of changes in organisations, such as learning structures and processes, to make managers' self-questioning possible, regarding their position and relations with the natural environment [55]; but this situation and/or 
task is a complex challenge faced by organisations and managers [26], as there is some uncertainty and complexity with regard to the continuous changes in organisations' environments and strategic management, in this case corporate sustainability, is implicitly long-term [1]. Therefore achieving a balance between this uncertainty and the time horizon may represent one difficulty of integrating this sustainability in organisations' global strategy $[65,66]$. This balance is clearly crucial for organisations to promote conditions of stability and consistency in their organizational structures and processes [1], but that responsibility must be assumed at the management level.

Therefore, for an organization to become sustainable, covering the three dimensions, it faces a certain pragmatism [1], with the moderating and/or influencing factors being summarized in Table 5 .

Table 5. Moderating/influencing factors.

\begin{tabular}{cc}
\hline Authors & Factors \\
\hline Carcano [5], Hahn [67] & Organizational commitment \\
Windolph, Harms and Schaltegger [68] & Motivations of capital holders \\
Gupta and Kumar [69], Radomska [70] & Type of organisational culture \\
Radomska [70] & Type of leadership and the motivation of all \\
\hline
\end{tabular}

All these factors have to be managed, and so the integration of corporate sustainability in organisations' global strategy means the strategies to adopt must be carefully selected by top management [71], as these will be reflected in long-term organizational performance. In other words, strategic management promotes organizational efficiency [72] and is a response to the great dynamism of business and institutional environments, to ensure survival in the present and future [71]. The combined contributions of Mintzberg et al., Porter, Sharplin, [73-75] and Njiru [71] lead to considering that sustainable strategic management is a long-term orientation for organisations, leading to improved competitive advantage. However, for this to occur, they must carry out structural changes and adjust their organizational (nuclear and distinctive) competences in relation to the current interests of all stakeholders.

Consequently, many organisations have begun to consider the sustainability strategy as necessary to remain competitive [56] and academics have begun to distinguish sustainable organisations from traditional ones, with the former trying to respond to the challenge to achieve a balance between financial, social and environmental results. Teh and Corbitt [76] corroborated the importance of this balance, highlighting the relevance of adopting these three dimensions in formulating and implementing a strategy of sustainability.

Then again, Crittenden and Crittenden [77] argued that the factors destroying either a sustainable or traditional strategy are related to top managers' style of management, definition of a strategy based on weak policies and systems, implying the need to take corrective measures in terms of organizational processes and the respective structure, as well as a re-adaptation of organizational competences [78]. Therefore, these factors must be overcome at the stage of top management's formulation of the strategy, so that all its components are duly adapted [77].

In this connection, corporate responsibility begins to be recognized not as an obligation, representing accounting costs, but as a long-term investment that brings benefits shared by all stakeholders. However, as the environment is dynamic, corporate governance must be effective, i.e., it must originate improvements in financial operations and solve conflicts between stakeholders, promoting changes in the vision and mission and improving the quality of results [79]. This author concluded that corporate governance is a bonus for strategic management (although it must be continually monitored), as it is a lever between the financial and sustainable elements of organisations. This means there is a positive relationship between corporate governance, corporate sustainability and strategic management [80], where the premises inherent to the former were reconsidered (in terms of ethical and behavioral principles), due to the effects of recent financial scandals, which had effects on organisations' strategic management, with more creative and dynamic models being created. 
Consequently, this positive relation ensures that firms can continue with their objectives (micro level) and allocate their resources effectively (macro level), as argued by Saltaji [80].

The holistic combination/connection of these attributes allows introduction of the dynamic implementation of a strategy of corporate sustainability, where organisations experience some difficulties [81]. For organisations, sustainability means their conservation and stability of their activities, as claimed by this author. Furthermore, to benefit from the trade-offs of the design, formulation and implementation of a corporate sustainability strategy, it is fundamental to understand the meaning of that concept for organisations, including their managers' own values, according to the same author.

Organisations have to change from traditional to sustainable behavior, to have internal and external legitimacy and thereby create added value, i.e., contribute to the global value chain [82], as intangible assets take precedence over tangible ones today, where the former are considered valuable and important.

Given these organizational changes, the stages of the strategy (formulation, implementation and assessment) have changed dramatically since its creation in the early 1970s, surviving the failings of its original design and evolving to a viable system of strategic management or strategic thought. Standing out is a major change in the responsibility for team planning by top managers, decentralization to business units/departments/divisions and greater attention to the ever-changing environment, particularly concerning competitiveness and technology, as pointed out by Wilson [82]. This means that these stages have failed, formally, from the mechanical perspective, something that has been debated in the academic world since 1960, according to the same author. Between 1960 and 1970, this planning was widely appreciated by organisations, but limited [24] due to not including uncertainties [82].

Once more, globalization implies that organisations are increasingly flexible, and so the phases of their strategy should mirror that flexibility and reflect all the uncertainties of their surroundings [24,82]. Therefore, there is no good strategy common to all organisations [83]. The strategy's success depends on the efficiency and effectiveness of its stages (formulation, implementation, execution and assessment) and was also influenced by various factors (Table 6).

Table 6. Factors for successful/unsuccessful strategy and its planning.

\begin{tabular}{|c|c|}
\hline Authors & Factors \\
\hline $\begin{array}{c}\text { Okumus [84], Riccò and Guerci; Shen, Chanda, D'Netto and } \\
\text { Monga; Vele [85-87] }\end{array}$ & $\begin{array}{c}\text { Degree of resistance to change in the whole } \\
\text { organisational structure }\end{array}$ \\
\hline $\begin{array}{l}\text { Håkonsson, Burton, Obel and Lauridsen [88]; Jin and Bai [65]; } \\
\text { Miller, Hickson and Wilson; Rose and Cray [89,90] }\end{array}$ & Managers' individual competences and capacities \\
\hline $\begin{array}{c}\text { Finkelstein and Borg [91]; Hrebiniak [92]; Miller, Wilson and } \\
\text { Hickson; Radomska; Sharplin; Whelan-Berry and } \\
\text { Somerville }[93,94]\end{array}$ & Type of leadership (management style) \\
\hline Walker Jr and Ruekert [95] & Organisational processes \\
\hline Amirthan, Lavanya and Nithya [96]; Daft and Macintosh [97] & Control systems \\
\hline $\begin{array}{c}\text { Amirthan, Lavanya and Nithya [96]; Peljhan [98]; Zeps and } \\
\text { Ribickis [99] }\end{array}$ & Reward and incentive systems \\
\hline $\begin{array}{l}\text { Amirthan, Lavanya and Nithya [96]; Dess and Priem [100]; } \\
\text { Smith [101] }\end{array}$ & Managers' degree of organisational commitment \\
\hline $\begin{array}{c}\text { Amirthan, Lavanya and Nithya [96]; Whelan-Berry and } \\
\text { Somerville [94] }\end{array}$ & Changes to the mission and vision \\
\hline
\end{tabular}

For Rose and Cray [90], all these factors are rooted in the dynamism of strategic management. David [102] argued that the phases of strategic management can be defined as an art and/or science, as the strategy and its inherent processes are dynamic [103]. This art is being able to make the formulation and implementation of the strategy show, clearly, the mission and long-term objectives, the identification of external opportunities and threats and internal strengths and weaknesses [104], where practical execution of the actions associated with those phases should represent a true situation and not a worthless document [75,104] and have a suitable allocation of resources [71]. This means that all this process, in its various sequential stages, provides organizational stability, and consequently adds 
to organizational performance $[71,105]$. Since all these phases are chronological, their formalization is an unavoidable aspect for organisations $[84,104,106,107]$. This formalization is closely related to the use of appropriate tools for execution and diagnosis [104], and so a proliferation of these has been found [108] as an effective means to help with implementation, assessment and control/monitoring [109] of the strategy implemented. It is noted that this proliferation has been caused by the continuous evolution of technology [108]. Important also in all these phases of strategic management is the communication in the whole organizational structure [110], internal consensus [111] and the crucial consideration of external factors [73].

As such, the implementation process must be understood as an ally rather than an opponent, functioning side by side with the formulation, providing financially, socially and ethically responsible plans, so that the strategy can be implemented successfully [77].

Summarizing, it is crucial to think out of the box, i.e., considering that organisations' internal and external environment, their resources and their managers' capacity to coordinate are vehicles for the strategy's success in all its phases, but this is also dependent on having strategic thought [99].

This systematization of the formulation, implementation and assessment of the strategy presented in the previous paragraphs, generally speaking, is summarized in the argument of Crittenden and Crittenden [77], that "implementation of the strategy helps to create the future rather than inhibiting it". Naturally, this argument is based on the research of other authors who studied the factors destroying the strategy implementation process [78] and the processes associated with this [112,113]. These factors destroying the strategy must be overcome in the phase of formulating the strategy [77].

Implementation of the strategy implies emphasizing the corporate functions inside the organization [22]. According to this author, how these functions are executed in practice depends on the type of strategy adopted in those areas, i.e., their execution implies that the organizational structure and management processes are modified or adapted.

As a starting point, to integrate corporate sustainability in organisations' global strategy, Hrebiniak [92] considered that implementing this strategy implies that top management makes decisions and transforms them into practical actions. This author also claimed this implementation had to be preceded by crucial alterations in the organisational culture, which should have corporate governance as a premise and be reflected in its structure and in its business activities; operationalization of this strategy has short-term reflections on everyday management (operational management). However, functional managers must be in line with this short-term operationalization and with long-term strategic objectives, and so it is important to have a suitable control and incentive system [92].

Explaining these requirements better, the same author indicated that changes in business environments worldwide have caused changes in competitiveness and corruption levels, which is a concern for corporate governance. However, effective corporate governance includes changes in internal and external factors inherent to organisations and their strategic management [80].

To address the controversial aspects of the meaning of that implementation, Elkington [114] proposed the concept of tripartite sustainability (triple bottom line), i.e., the organization's sustainability can be measured in economic, environmental and social terms regarding its global effects and impacts. This question had already been raised by Stead and Stead [10,11].

Supported by the arguments of Hrebiniak [92] and Saltaji [80,81], i.e., as a positive consequence of their contributions, Klettner, Clarke and Boersma [115] showed the importance of building sustainable businesses, which had already been addressed by the Institute of Chartered Accounting/KPMG in 2011. This conclusion culminated in a dynamic, interactive model that begins by defining and formulating the strategy, followed by its implementation, forcing all the organization's internal processes to be sustainable (sustainability should be rooted as an intrinsic value) and all the reports/outputs produced to show the creation of added value [115]. However, these authors consider there must be organizational commitment by organisations' top management to take on that responsibility and they must make major efforts to achieve a balance between financial performance and sustainable performance. 
The formulation and implementation of a strategy covering the three dimensions (tripartite sustainability) of corporate sustainability has proved not to be an easy task, but a very complex challenge for organisations and their managers, since they must also keep thinking about their growth and continued operations [81]. For this author, some organisations perceive sustainability as an opportunity to improve their image and reputation, rather than considering social or environmental initiatives. Others present sustainability reports, but when these are analyzed by the relevant authorities, they do not reveal much added value, despite the growing importance of drawing up these reports. Many organisations did not have leaders with the capacity to implement this concept, and moreover, the organizational culture of some hinders that implementation.

Then again, the research by the Conference-Board [116], based on interviews with business executives, reported that factors that may hinder a successful strategy of corporate sustainability are: clear articulation between leadership and the new identity the organization must assume, particularly regarding its values and mission; the existence of a strong economic model underlying the business; senior managers' philosophy and style must transmit confidence to the new entity. Baumgartner [117], Epstein, Buhovac and Yuthas [118] also found that leadership and culture are the most limiting factors of this strategy's success, including its implementation. They clarify that a great many managers visualize that strategy as something good for the organization in terms of public relations, rather than incorporating it in their objectives, in their global strategy and operational plans. Formally, sustainability strategies and the structures supporting them do not ensure that decision-making to make the necessary investment by itself implies practical progress of those strategies [81]. This decision must be associated with collaborators' education, correct and constant communication and its integration in all organizational processes [81]. Therefore, formulation and implementation of the sustainability strategy, among other aspects, requires major investment in organizations' intangible assets and appropriate allocation of tangible and intangible assets, which will take a long time, according to this author. Collaborators (intangible resources) may naturally demonstrate some resistance to these changes, increasing the time taken to integrate the strategy, and this can also represent a risk to achieving successful integration (possibly imposing implementation of a weak strategy with effects on competitive advantages in the sector [81]. In addition, this author sees the sustainability strategy as a responsibility held in trust by organisations, and so they must set all their assets to produce benefits for all stakeholders, make decisions based on the three dimensions of sustainability and draw up reports emphasizing their potential, particularly for financial performance.

To improve implementation of the sustainability strategy, managers must take care to identify and measure the drivers of performance, covering various inputs and processes. These drivers are the external context (regulatory and geographical), the internal context (mission, corporate strategy, organizational structure and culture, systems and the business context) and financial and human resources [118]. Inputs, therefore, guide top managers in decision-making, so that they can formulate an appropriate sustainability strategy and allow aligned configuration of structures, programmed and systems, to advance subsequently with practical actions. In turn, these actions lead to (positive/negative) sustainability performance and reactions from all stakeholders, which ultimately affect the organization's long-term corporate performance. Finally, this identification of inputs and processes helps managers to make a more efficient analysis of these drivers and improve the level of social and environmental impacts [118]. These authors also clarify that most of the literature on the implementation of this strategy focuses on formal systems and incentive systems, but these per se do not have any effect on its success, since they must be included in a wider set of systems and processes. These combinations and processes must be constructed based on objectivity and equity and be measurable. Obviously, these must include the three dimensions of sustainability, despite the social and environmental dimensions being intangible and more difficult to measure [118].

More recently, Baumgartner [22] claimed there are different approaches, instruments and tools to support organisations in managing corporate sustainability, but that management requires a wide-ranging, integrated vision $[119,120]$, namely, in strategic terms, where this integration is a 
pre-requisite of success $[117,121,122]$. Summarizing, Baumgartner [22] underlined that the contextual factors (the business's juridical status, surrounding environment, sector of activity and stakeholders) of corporate sustainability have to be assessed in the three dimensions of sustainable development, and this assessment must be on a scale (low, average and high). It is also highlighted that the sector factors are based on the five competitive forces of Porter [123,124].

Baumgartner and Ebner [3] state that the corporate sustainability strategy can be an introvert (mitigation), extrovert (external legitimacy), conservative (efficiency) and visionary (global sustainability). However any of them must be duly developed, with the starting point being identification of all contextual factors, applied at the normative, strategic and operational level. However, it is in the last-named that the strategy is effectively implemented and executed [22]. That is, they built a model for the integration of a sustainable strategy in organisations, in which there must be normative management (definition of the basic philosophy of management, including values, attitudes, beliefs and basic judgments-Where are we and where do we want to go?-reflecting internal and external legitimacy), strategic management (definition of long-term objectives and their articulation with the environment-What are our strategic objectives? - for these to become effective) and operational management (covering the whole organization and management of all corporate activities, in order to reach strategic objectives efficiently) [22].

Summarizing, this model can be used in all types of organisations, whatever their size and sector of activity, as it gives organisations a real sustainability strategy that is effective in practical terms, particularly its formulation and implementation, ensuring the connection of sustainable development at the three levels of management and with added value in social and environmental terms in harmony with economic performance (three dimensions of sustainability) [22].

The International Standardization Organization (ISO) 26000—Social Responsibility [125]—also considers that organisations do not operate in a vacuum, that their relationship with society and the environment in which they operate is a critical factor in their capacity to continue to operate effectively. This norm provides orientations as to how organisations can operate in a socially responsible way. This means acting ethically and transparently, contributing to society's health and well-being [125]. It also establishes the stages for developing a sustainability strategy, where the three dimensions are interlinked with strategic management [66]. Based on this norm, the phases of corporate sustainability strategy management are an integral part of a global process [68] divided in four process elements which are: internal and external auditing, formulation of the strategy (statement of the mission and vision, definition of long-term objectives), its implementation and assessment in terms of performance (www.iso.org/iso/home/standards/iso26000, 2010).

The contributions of Baumgartner $[22,117,126]$ corroborate and are directed to those four elements by ISO26000 (2010), i.e., the model it presents is guided by the three types of management and by the three types of dimensions referred to, which include the premises of this norm, and the phases of the strategy have to be supported by appropriate instruments (auditing, information systems, budgets, performance indicators and risk analysis) and will always consider corporate governance (its practices allow assessment/monitoring of the strategy implemented and its dynamic adjustment in relation to that assessment) and corporate culture (organisational culture is a crucial factor), in order to reach long-term objectives [102].

Throughout this analysis, a hiatus was found between the formulation and implementation of the corporate sustainability strategy, which can generate tension/conflict in respect to its three dimensions, whose recognition and identification is crucial [127] in order to choose the appropriate strategies, as these occur at different organizational levels and contexts but must be considered simultaneously.

It is also important to measure the three dimensions of corporate sustainability strategy, so that stakeholders know the financial value of the actions implemented through organisations' adoption of that strategy [128-131].

From another, but creative and innovative perspective, Lampikoski et al., [132] argued that corporate sustainability strategies generating value are regarded as green initiatives, but as if it was a 
game, i.e., these initiatives are understood to have similar characteristics to games where the role of managers is still fundamental.

Finally, Table 7 summarizes all the contributions of the authors referred to above, aiming to help organisations' top management to formulate and implement their corporate sustainability strategy, so that their organisations and business can be sustainable.

Table 7. Summary of contributions.

\begin{tabular}{|c|c|c|}
\hline State-of-the-Art & Dimensions & Contributions \\
\hline $\begin{array}{l}\text { Corporate sustainability and its } \\
\text { integration in global strategy }\end{array}$ & $\begin{array}{c}\text { Real } \\
\text { Saltaji }[79,80]\end{array}$ & $\begin{array}{l}\text { Review of the premises of corporate governance as the } \\
\text { consequence of the effects of recent financial scandals, which } \\
\text { originated the need for more creative and dynamic models of } \\
\text { strategic management, to allow integrating corporate } \\
\text { sustainability in the global strategy. } \\
\text { Organisations and their business should be more sustainable and } \\
\text { corporate governance practices should be adopted, to ensure: }\end{array}$ \\
\hline $\begin{array}{l}\text { Corporate sustainability versus } \\
\text { formulation and implementation } \\
\text { of sustainable strategy }\end{array}$ & $\begin{array}{l}\text { Alteration Crittenden and } \\
\quad \text { Crittenden [77] }\end{array}$ & $\begin{array}{l}\text { Having organisational awareness of the need for internal } \\
\text { structural changes and the values of organisational culture, } \\
\text { implying great commitment by managers. }\end{array}$ \\
\hline \multirow[b]{2}{*}{$\begin{array}{l}\text { Formulation and implementation } \\
\text { of sustainable strategy }\end{array}$} & \multirow[b]{2}{*}{$\begin{array}{c}\text { Practical Beer and Eisenstat [78] } \\
\text { Bonoma and Crittenden [112] } \\
\text { Crittenden and Crittenden [77] } \\
\text { David [102] } \\
\text { Thompson Jr et al. [113] } \\
\text { Baumgartner [22], [117], [126] } \\
\text { Hahn [66] } \\
\text { Hahn et al. (2014) [127] } \\
\text { Saltaji [79], [80] } \\
\text { Stead and Stead (2000) [55] }\end{array}$} & $\begin{array}{l}\text { (2) It is necessary to make crucial decisions and implement } \\
\text { them in practical terms (hiatus). }\end{array}$ \\
\hline & & $\begin{array}{l}\text { (3) It is crucial to carry out internal and external diagnosis } \\
\text { (internal and external auditing)—normative management } \\
\text { that provides internal and external legitimacy; formulation } \\
\text { of strategy (mission, vision and definition of long-term } \\
\text { objectives)—strategic management, which originates } \\
\text { effectiveness); implementation of the strategy, assessment } \\
\text { and measuring of its results—operational management, } \\
\text { which represents efficiency. }\end{array}$ \\
\hline
\end{tabular}

This table aims to summarize all the relevant information that should be taken into consideration in these phases, setting out from the real dimension to the theoretical dimension, which simultaneously allows passing to the practical dimension and to results in a holistic way. In addition, the importance of changing strategic thought strengthens the interactive cycle of sustainable (and even traditional) strategic management, which implies that organisations and their managers take on a commitment to the business and simultaneously to society in general. That commitment is fundamental for there to be a balance between financial performance and sustainable performance. It is precisely in reaching this balance that the hiatus between formulation and implementation lies, i.e., managers must pass from theory to practice efficiently and effectively, so that their organisations can contribute effectively to the sustainable development that is so important for future generations.

The major contribution of this study lied in the presentation of a framework aimed at the firms, because in magazines with this objetives, there is a certain shortage. For example, Alshehhi et al. [133] studied the impact of corporate sustainability on financial performance, identifying the topics that stand out in the literature, concluding that more attention has been given to the social dimension over the economic and environmental dimension, presenting a framework that bridges this gap. On the other hand, Ramos-González et al. [134] studied how a sustainable entrepreneur's behavior can 
positively affect corporate reputation/internal and external legitimacy, concluding that sustainable and responsible management is as crucial as ethical behavior of people for that reputation.

The extensive literature reviewed in this study allowed definition of a framework summarizing the pertinent information that must be considered when implementing a corporate sustainable strategy, setting out from the real dimension to the theoretical dimension, which simultaneously allows passing to the practical dimension and to results (Figure 3). This model reflects the diagnosis of the internal and external environment, the definition of the mission and objectives, plans and policies (formulation), in order to obtain a competitive advantage over the competition. The implementation phase includes programs, budgets and procedures, while assessment and monitoring include calculating the performance of the defined strategy.

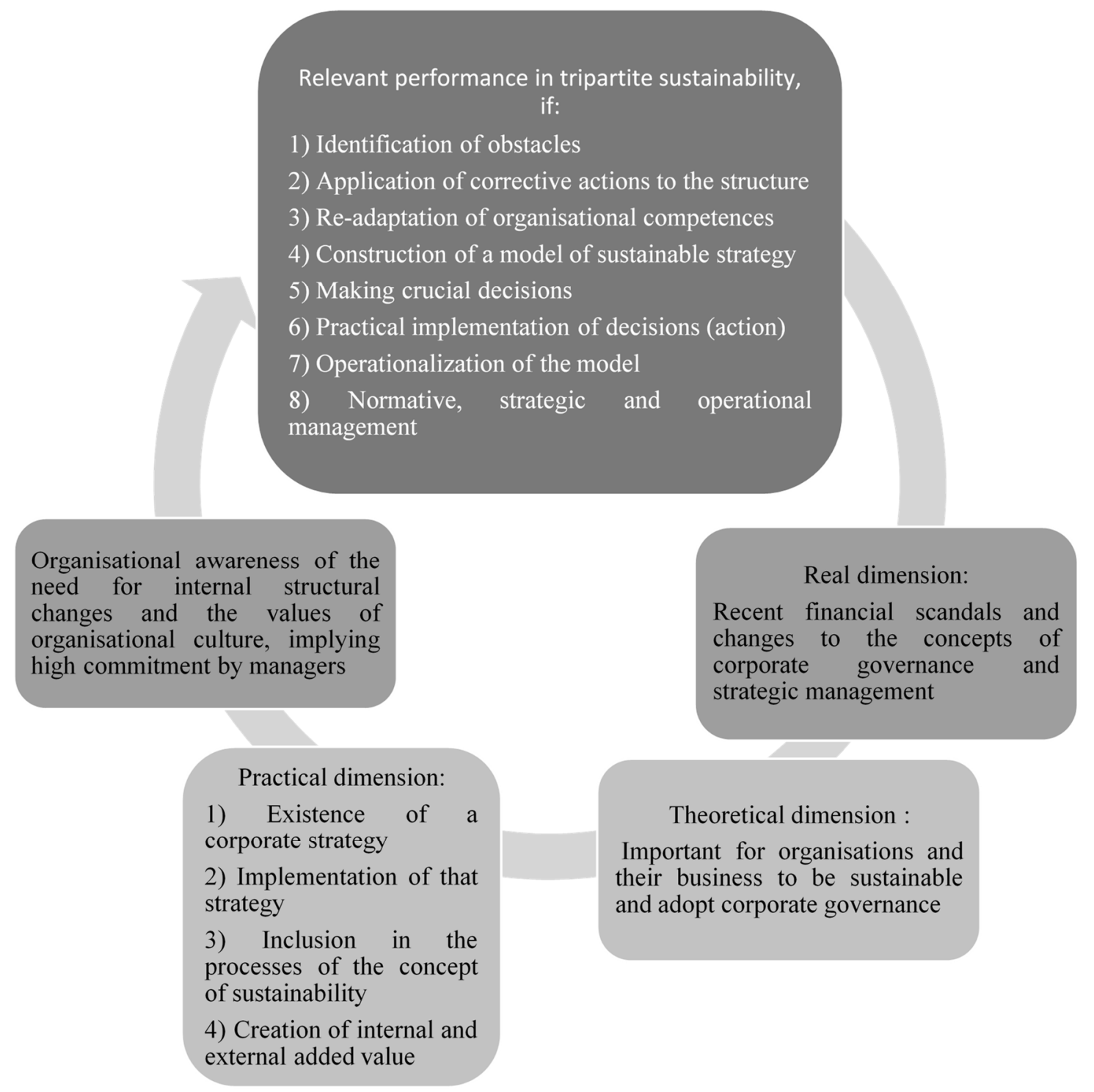

Figure 3. Framework for a corporate sustainable strategy in firms.

It should be noted that the implementation of a corporate sustainability strategy, for Moldavska [135], is dependent on factors such as the commitment of business leaders, available resources, how this type of strategy is communicated and the organizational climate. On the other hand, these strategies also lack control and monitoring of the results obtained with their implementation [136]. In this sense, Radomska [104] argued that the process of implementing a sustainable strategy includes 
the implementation, implementation and control/monitoring phase, which should be flexible and adaptable to internal and external conditions.

\section{Conclusions and Implications}

This conceptual study addressed corporate sustainability and organisations' strategic management, intending to compile the extensive scientific information existing on the subject, in order to provide the scientific community and managers with an integrated vision from its origins until the present time. A growing tendency for studies to be consensual was also found, regarding the pertinence of the topic, given the phenomenon of globalization and the heterogeneity of business environments. However, the evidence obtained lets us argue that more research is still needed into the formulation and implementation of a sustainable strategy in organisations, particularly empirical studies (Engert and Baumgartner, [23]; Engert et al., [1]), in order to construct appropriate models combining the three dimensions of corporate sustainability with organisations' objectives, competitive advantage and internal/external legitimacy. This argument is the result of the extensive literature review, where some controversial points or obstacles were noted (e.g., organizational culture, competences, among others), which can influence the success of that formulation and implementation, but which are based on common premises.

This study led to the conclusion that organisations are a bridge towards coming closer to true global sustainability, meaning they allow the creation of intangible value for new models of economic growth, which include tripartite sustainability as an inseparable pillar for both organisations and society in general. Organisations must therefore implement sustainable strategies as an integral part of their growth and competitiveness strategy, to maximize their resources and have a positive impact on their performance.

The formulation and implementation of a corporate sustainability strategy in organisations still needs more conceptual and empirical studies, to equip top management with a solid basis to formulate and implement that strategy successfully and thereby contribute to sustainable development [22,129]. This systematization revealed a tendency towards consensus that the formulation and implementation of this strategy must include management processes oriented towards systems, policies and practices, as well as their integration and coordination, considering managers' competences. There is also the need for continuous monitoring and assessment [65]. Stead and Stead [55] already highlighted the importance of this formulation and implementation being designed to provide organisations with competitive advantages, through the use of corporate responsibility.

As an implication for theory, it is argued that the resource and market-based visions are appropriate in framing this topic, as organisations should always pay attention to their resources and their position in the market, for suitable definition of their sustainable strategy. However, difficulties in the processes of building and implementing a sustainable strategy are no different from the traditional strategy, despite being set in different contexts, finding additional complexity regarding the demands of all stakeholders, the degree of organizational commitment and the organizational and individual competences of managers/collaborators [1].

As implications for practice, first of all it is believed this study can help researchers and managers to identify potential strengths and weaknesses in the formulation and implementation of their sustainable strategy, to understand what their strategic position is, and what strategy they should follow. Secondly, the systematization carried out allowed construction of an innovative framework, providing an orientation for organisations to follow in their sustainability strategy, for them to become successful and sustainable. Finally, it contributed to highlighting that when organisations adopt strategies directed towards sustainability, this means all stakeholders feel involved in the process, which gives legitimacy to, and awareness of the tripartite responsibilities assumed by their managers.

This study is not without limitations. Using only the WOS database is one limitation, despite its credibility being unquestionable. The second limitation refers to the theoretical framework, as many 
other theories could have been used, for example, stakeholder theory. The third limitation concerns the non-use of relevant statistical tests, which should be addressed in future research on this topic.

As for future research, empirical literature is still needed on how this strategy is formulated and implemented in practical terms in organisations, study of the role of motivation and communication between all the organization's collaborators for that implementation, and study of the importance and level of organizational commitment that should be assumed by managers/collaborators in the phase of implementing and executing the strategy. It is of note that the negative impacts of leadership styles, different organizational cultures, ineffective instruments and weak information systems affect successful implementation of a strategic model of corporate sustainability, and so this topic also suggests various paths for future research. Other future research is an empirical study on the implementation of this strategy in listed companies through a quantitative methodology, such as the one performed [137]. A final suggestion would be to include the circular economy model in organisations' sustainable strategies, to generate new opportunities and improve competitive advantage.

Author Contributions: M.R. had the initial idea of the manuscript and wrote an original draft, as well as provided the resources for the research and M.F. participated in the formal reviews and supervision.

Funding: This research was not funded.

Acknowledgments: The authors thank the anonymous reviewers for their very helpful comments that contributed to the development of this paper. The authors gratefully acknowledge financial support from National Funds of the FCT—Portuguese Foundation for Science and Technology within the project «UID/ECO/04007/2019».

Conflicts of Interest: The authors declare no conflict of interest.

\section{References}

1. Engert, S.; Rauter, R.; Baumgartner, R.J. Exploring the integration of corporate sustainability into strategic management: A literature review. J. Clean. Prod. 2016, 112, 2833-2850. [CrossRef]

2. Lee, M.D.P. Configuration of External Influences: The Combined Effects of Institutions and Stakeholders on Corporate Social Responsibility Strategies. J. Bus. Ethics 2011, 102, 281-298. [CrossRef]

3. Baumgartner, R.J.; Ebner, D. Corporate sustainability strategies: Sustainability profiles and maturity levels. Sustain. Dev. 2010, 18, 76-89. [CrossRef]

4. van Marrewijk, M.; Werre, M. Multiple levels of corporate sustainability. J. Bus. Ethics 2003, 44, 107-119. [CrossRef]

5. Carcano, L. Strategic Management and Sustainability in Luxury Companies. J. Corp. Citizsh. 2013, 2013, 36-54.

6. Gladwin, T.N.; Kennelly, J.J.; Krause, T. Shifting Paradigms for Sustainable for Implications Development: And Theory. Acad. Manag. Rev. 1995, 20, 874-907. [CrossRef]

7. Shrivastava, P. Is Strategic Management Ideological? J. Manag. 1986, 12, 363. [CrossRef]

8. Hambrick, D.C.; Fredrickson, J.W.S. Are you sure you have a strategy? Acad. Manag. Perspect. 2001, 15, 48-59. [CrossRef]

9. Ronda-Pupo, G.A.; Guerras-Martin, L.Á. Dynamics Of The Evolution Of The Strategy Concept 1962-2008: A Co-Word Analysis. Strateg. Manag. J. 2012, 33, 162-188. [CrossRef]

10. Stead, J.G.; Stead, W.E. Sustainable strategic management: An evolutionary perspective. Int. J. Sustain. Strateg. Manag. 2008, 1, 62-81. [CrossRef]

11. Stead, J.G.; Stead, E.W. Management for a Small Planet: Strategic Decision Making and the Environment, 2st ed.; Routledge: Abingdon, UK, 1996.

12. World Economic Commission on Environment and Development. Available online: https://idlbnc-idrc.dspacedirect.org/bitstream/handle/10625/152/WCED_v17_doc149.pdf?sequence=1 (accessed on 22 June 2018).

13. Bansal, P. Evolving sustainably: A longitudinal study of corporate sustainable development. Strateg. Manag. J. 2005, 26, 197-218. [CrossRef]

14. Bansal, P. The corporate challenges of sustainable development. Acad. Manag. Perspect. 2002, 16, $122-131$. [CrossRef]

15. Porter, M.E. Towards a dynamic theory of strategy. Strateg. Manag. J. 1998, 12, 95-117. [CrossRef] 
16. Barney, J. Firm Resources and Sustained Competitive Advantage. J. Manag. 1991, 17, 99-120. [CrossRef]

17. Nawaz, M.; Koc, W. Development of a systematic framework for sustainability management of organisations. J. Clean. Prod. 2018, 171, 1255-1274. [CrossRef]

18. Calabrese, A.; Costa, R.; Levialdi, N.; Menichini, T. Technological Forecasting \& Social Change Integrating sustainability into strategic decision-making: A fuzzy AHP method for the selection of relevant sustainability issues. Technol. Forecast. Soc. Chang. 2018, 139, 155-168.

19. Batista, A.; Francisco, A. Organizational Sustainability Practices: A Study of the Firms Listed by the Corporate Sustainability Index. Sustainability 2018, 10, 226. [CrossRef]

20. Rok, B. Transition from Corporate Responsibility to Sustainable Strategic Management. In Corporate Social Responsibility in Poland; Springer: Berlin/Heidelberg, Germany, 2019; pp. 3-18.

21. Perrott, B. The sustainable organisation: Blueprint for an integrated model. J. Bus. Strategy 2014, 35, $26-37$. [CrossRef]

22. Baumgartner, R.J. Managing corporate sustainability and CSR: A conceptual framework combining values, strategies and instruments contributing to sustainable development. Corp. Soc. Responsib. Environ. Manag. 2014, 21, 258-271. [CrossRef]

23. Engert, S.; Baumgartner, R.J. Corporate sustainability strategy-Bridging the gap between formulation and implementation. J. Clean. Prod. 2016, 113, 822-834. [CrossRef]

24. Adiningrum, T.S. Strategic Planning: Shaping Organisation Action Or Emerging From Organisational Action? J. Bus. Strategy Exec. 2012, 5, 46-54.

25. Li, Y.; Guohui, S.; Eppler, M.J. Making Strategy Work: A Literature Review on the Factors Influencing Strategy Implementation. In Handbook of Strategy Process Research; Edward Elgar Publishing Limited: Cheltenham, UK, 2010.

26. Bonn, I.; Fisher, J. Sustainability: The missing ingredient in strategy. J. Bus. Strategy 2011, 32, 5-14. [CrossRef]

27. Abele-Brehm, A.E. (Ed.) Wohlbefinden: Theorie, Empirie, Diagnostik; Juventa-Verlag: Weinheim, Germany, 1991.

28. White, H.D.; McCain, K.W. Visualizing a discipline: An author co-citation analysis of information science, 1972-1995. J. Am. Soc. Inf. Sci. 1998, 49, 327-355.

29. Quinlan, K.M.; Kane, M.; Trochim, W.M.K. Evaluation of large research initiatives: Outcomes, challenges, and methodological considerations. New Dir. Eval. 2008, 2008, 61-72. [CrossRef]

30. Grácio, C.M.C. Acoplamento bibliográfico e análise de cocitação: Revisão teórico-conceitual. Encontros Bibli 2016, 21, 82-99. [CrossRef]

31. Prasad, S.; Tata, J. Publication patterns concerning the role of teams/groups in the information systems literature from 1990 to 1999. Inf. Manag. 2005, 42, 1137-1148. [CrossRef]

32. Treinta, F.T.; Filho, J.R.F.; Sant'Anna, A.P.; Rabelo, L.M. Metodologia de pesquisa bibliográfica com a utilização de método multicritério de apoio à decisão. Production 2014, 24, 508-520. [CrossRef]

33. Seuring, S.; Mu, M. From a literature review to a conceptual framework for sustainable supply chain management. J. Clean. Prod. 2008, 16, 1699-1710. [CrossRef]

34. Tranfield, D.; Denyer, D.; Smart, P. Towards a Methodology for Developing Evidence-Informed Management Knowledge by Means of Systematic Review. Br. J. Manag. 2003, 14, 207-222. [CrossRef]

35. Gmür, M. Co-citation analysis and the search for invisible colleges: A methodological evaluation. Scientometrics 2003, 57, 27-57. [CrossRef]

36. Jeong, Y.K.; Song, M.; Ding, Y. Content-based author co-citation analysis. J. Informetr. 2014, 8, $197-211$. [CrossRef]

37. Small, H. Co-citation in the scientific literature: A new measure of the relationship between two documents. J. Am. Soc. Inf. Sci. 1973, 24, 265-269. [CrossRef]

38. van Eck, N.J.; Waltman, L. Software survey: VOSviewer, a computer program for bibliometric mapping. Scientometrics 2010, 84, 523-538. [CrossRef] [PubMed]

39. Waltman, L.; van Eck, N.J.; Noyons, E.C.M. A unified approach to mapping and clustering of bibliometric networks. J. Informetr. 2010, 4, 629-635. [CrossRef]

40. Becker, S.; Bryman, A.; Ferguson, H. Understanding Research for Social Policy and Social Work: Themes, Methods and Approaches; Policy Press: Bristol, UK, 2012.

41. Ryan, B.; Scapens, R.W.; Theobold, M. Research Method and Methodology in Finance and Accounting, 2nd ed.; Cengage Learning: Boston, MA, USA, 2002. 
42. Yin, R. Case Study Research: Design and Methods-Applied Social Research Methods Series, 4th ed.; Sage Publications, Inc.: Thousand Oaks, CA, USA, 2009.

43. Rehn, C.; Kronman, U. Bibliometric Handbook for Karolinska Institutet; Karolinska Institutet: Huddinge, Sweden, 2008; pp. 1-36.

44. Hart, S. A natural resource based view of the firm. Acad. Manag. Rev. 1995, 20, 986-1014. [CrossRef]

45. Russo, M.V.; Fouts, P.A. A Resource-Based Perspective On Corporate Environmental Performance And Profitability. Acad. Manag. J. 1997, 40, 534-559.

46. Sharma, S. Managerial Interpretations and Organizational Context as Predictors of Corporate Choice of Environmental Strategy. Acad. Manag. J. 2000, 43, 681-697.

47. Bansal, P. Why Companies Go Green: A Model Of Ecological Responsiveness University of Western Ontario. Acad. Manag. J. 2000, 43, 717-736.

48. Porter, M. Green and Competitive: Ending the Stalemate. Haward Bus. Rev. 1995, 73, 120-124.

49. Porter, E.; Kramer, M.R.; Porter, E.; Kramer, M.R. Estrategia y sociedad Estrategia y sociedad. Haward Bus. Rev. 2006, 84, 42-56.

50. Freeman, R.E. Strategic Management: A Stakeholder Approach; Cambridge University Press: Cambridge, UK, 1984.

51. Garriga, E. Corporate Social Responsibility Theories: Mapping the Territory. J. Bus. Ethics 2004, 53, 51-71. [CrossRef]

52. Carter, C.R.; Rogers, D.S. A framework of sustainable supply chain management: Moving toward new theory. Int. J. Phys. Distrib. Logist. Manag. 2008, 38, 360-387. [CrossRef]

53. Vachon, S.; Klassen, R.D. Extending green practices across the supply chain integration. Int. J. Oper. Prod. Manag. 2006, 26, 795-821. [CrossRef]

54. Porter, M.E. Competitive Strategy: Techniques for Analyzing Industries and Companies; Simon and Schuster: New York, NY, USA, 1980.

55. Stead, J.G.; Stead, E. Eco-Enterprise Strategy: Standing for Sustainabilit. J. Bus. Ethics 2000, 24, $313-329$. [CrossRef]

56. Dyllick, T.; Hockerts, K. Beyond the Business Case for Corporate Sustainability. Bus. Strateg. Environ. Bus. Strat. Environ. 2002, 11, 130-141. [CrossRef]

57. Kiron, D.; Kruschwitz, N.; Haanaes, K. Sustainability Nears a Tipping Point. MIT Sloan Manag. Rev. 2012, 53, 69-74. [CrossRef]

58. Porter, M.E.; Kramer, M.R. Creating shared value. Harv. Bus. Rev. 2011, 89, 62-77.

59. Shrivastava, P.; Scott, H.I. Corporate self-greenewal: Strategic responses to environmentalism. Bus. Strategy Environ. 1992, 1, 9-21. [CrossRef]

60. Throop, G.M.; Starik, M.; Rands, G.P. Rands Sustainable strategy in a greening world: Integrating the natural environment into strategic management. Adv. Strateg. Manag. 1993, 9, $63-92$.

61. Kiernan, M.J. The eco-industrial revolution: Reveille or requiem for international business. Bus. Contemp. World 1992, 4, 133-143.

62. Shrivastava, P. Ecocentric management for a risk society. Acad. Manag. Rev. 1995, 20, 118-137. [CrossRef]

63. Shrivastava, P. The role of corporations in achieving ecological sustainability. Acad. Manag. Rev. 1995, 20, 936-960. [CrossRef]

64. Lozano, R. Are companies planning their organisational changes for corporate sustainability? An analysis of three case studies on resistance to change and their strategies to overcome it. Corp. Soc. Responsib. Environ. Manag. 2013, 20, 275-295. [CrossRef]

65. Jin, B.Z.; Bai, Y. Sustainable Development and Long-Term Strategic Management Embedding a Long-Term Strategic Management System into Medium and Long-Term Planning. World Future Soc. 2011, 3, 49-70. [CrossRef]

66. Hahn, R. ISO 26000 and the standardization of strategic management processes for sustainability and corporate social responsibility. Bus. Strategy Environ. 2013, 22, 442-455. [CrossRef]

67. Galbreath, J. Corporate social responsibility strategy: Strategic options, global considerations. Corp. Gov. 2006, 6, 175-187. [CrossRef]

68. Windolph, S.E.; Harms, D.; Schaltegger, S. Motivations for corporate sustainability management: Contrasting survey results and implementation. Corp. Soc. Responsib. Environ. Manag. 2014, 21, 272-285. [CrossRef] 
69. Gupta, S.; Kumar, V. Sustainability as corporate culture of a brand for superior performance. J. World Bus. 2013, 48, 311-320. [CrossRef]

70. Radomska, J. The Role of Managers in Effective Strategy Implementation. Int. J. Contemp. Manag. 2014, 13, 77-86.

71. Njiru, G.M. Implementation of Strategic Management Practices in The Water and Sanitation Companies in Kenya. Strateg. J. Bus. Chang. Manag. 2014, 2, 841-856.

72. Price, A.D.F.; Newson, E. Strategic Management: Consideration of Paradoxes, Processes, and Associated Concepts as Applied to Construction. J. Manag. Eng. 2003, 19, 183-192. [CrossRef]

73. Mintzberg, H.; Ahlstrand, B.; Lampel, J. Strategy Safari: A Guided Tour Through the Wilds of Strategic Management; Simon and Schuster: New York, NY, USA, 1998.

74. Porter, M.E. America's green strategy. Sci. Am. 1991, 264, 168. [CrossRef]

75. Sharplin, A. Strategic Management; McGraw-Hill Education: New York, NY, USA, 1985.

76. Teh, B.; Corbitt, D.E. Building sustainability strategy in business. J. Bus. Strategy 2015, 36, 39-46. [CrossRef]

77. Crittenden, V.L.; Crittenden, W.F. Building a capable organization: The eight levers of strategy implementation. Bus. Horiz. 2008, 51, 301-309. [CrossRef]

78. Beer, M.; Eisenstat, R.A. The Silent Killers of Strategy Implementation and Learning. Sloan Manag. Rev. 2000, $41,29-40$.

79. Saltaji, I.M. Corporate Governance Relationship With Strategic Management. Intern. Audit. Risk Manag. 2013, 8, 293-300.

80. Saltaji, M.F. Corporate governance relation with corporate sustainability. Intern. Audit. Risk Manag. 2013, 8, 137-147.

81. John, S. Implementing Sustainability Strategy: A Community Based Change Approach. Int. J. Bus. Insights Transform. 2012, 4, 16-20.

82. Wilson, I. Strategic planning isn't dead-It changed. Long Range Plann. 1994, 27, 12-24. [CrossRef]

83. Dass, P.; Parker, B. Strategies for managing human resource diversity. Acad. Manag. Perspect. 1999, 13, 68-80. [CrossRef]

84. Okumus, F. A framework to implement strategies in organisations. Manag. Decis. 2003, 41, 871-882. [CrossRef]

85. Riccò, R.; Guerci, M. Diversity challenge: An integrated process to bridge the 'implementation gap'. Bus. Horiz. 2014, 57, 235-245. [CrossRef]

86. Shen, J.; Chanda, A.; D’Netto, B.; Monga, M. Managing diversity through human resource management: An international perspective and conceptual framework. Int. J. Hum. Resour. Manag. 2009, 20, 235-251. [CrossRef]

87. Vele, C.L. Evaluating the strategy implementation process. Manag. Chall. Contemp. Soc. 2012, 4, $192-195$.

88. Håkonsson, D.D.; Burton, R.M.; Obel, B.; Lauridsen, J.T. Strategy Implementation Requires the Right Executive Style: Evidence from Danish SMEs. Long Range Plan. 2012, 45, 182-208. [CrossRef]

89. Miller, S.; Hickson, D.; Wilson, D. From Strategy to Action. Involvement and Influence in Top Level Decisions. Long Range Plan. 2008, 41, 606-628. [CrossRef]

90. Rose, W.R.; Cray, D. The Role of Context in the Transformation of Planned Strategy into Implemented Strategy. J. Bus. Manag. Econ. Res. 2013, 4, 721-737.

91. Finkelstein, S.; Borg, S. Strategy gone bad: Doing the wrong thing. Handb. Bus. Strateg. 2004, 5, 115-124. [CrossRef]

92. Hrebiniak, L.G. Obstacles to effective strategy implementation. Organ. Dyn. 2006, 35, 12-31. [CrossRef]

93. Miller, S.; Wilson, D.; Hickson, D. Beyond planning: Strategies for successfully implementing strategic decisions. Long Range Plan. 2004, 37, 201-218. [CrossRef]

94. Whelan-Berry, K.S.; Somerville, K.A. Linking Change Drivers and the Organizational Change Process: A Review and Synthesis. J. Chang. Manag. 2010, 10, 175-193. [CrossRef]

95. Walker, O.C., Jr.; Ruekert, R.W. Marketing's Role in the Implementation of Business Strategies: A Critical Review and Conceptual Framework. J. Mark. 1987, 51, 15-33. [CrossRef]

96. Amirthan, J.; Lavanya, L.P.; Nithya, V.E. Strategic Management: Formulation and Implementation. Imp. J. Interdiscip. Res. 2016, 2, 835-836.

97. Daft, R.L.; Macintosh, N.B. The Nature and Use of Formal Control Systems for Management Control and Strategy10 Implementation. J. Manag. 1984, 10, 43-46. 
98. Peljhan, D. The Role of Management Control Systems in Strategy Implementation: The Case of a Slovenian Company. Econ. Bus. Rev. 2007, 9, 257-280.

99. Zeps, A.; Ribickis, L. Strategy Development and Implementation-Process and Factors Influencing the Result: Case Study of Latvian Organisations. Procedia-Soc. Behav. Sci. 2015, 213, 931-937. [CrossRef]

100. Dess, G.G.; Priem, R.L. Consensus-Performance Research: Theoretical and Empirical Extensions. J. Manag. Stud. 1995, 32, 401-417. [CrossRef]

101. Smith, B.D. Maybe I will, maybe I won't: What the connected perspectives of motivation theory and organisational commitment may contribute to our understanding of strategy implementation. J. Strateg. Mark. 2009, 17, 473-485. [CrossRef]

102. David, F.R. Concepts of Strategic Management, 6th ed.; Prentice Hall: New Jersey, NJ, USA, 1997.

103. Stahl, D.W.; Grigsby, M.J. Strategic Management: Formulation and Implementation; Van Nostrand Reinhold: Boston, MA, USA, 1992.

104. Radomska, J. Formalization in strategy implementation-The key to sucess or an unnecessary limitation? Int. J. Contemp. Manag. 2013, 12, 80-92.

105. Certo, J.P.; Peter, S.C. Strategic Management Concepts and Applications; McGraw Hill, Inc.: New York, NY, USA, 1991.

106. Mintzberg, H.; Waters, J.A. Of Strategies, Deliberate and Emergent. Strateg. Manag. J. 1985, 6, $257-272$. [CrossRef]

107. Agarwal, R.; Grassl, W.; Pahl, J. Meta-SWOT: Introducing a new strategic planning tool. J. Bus. Strategy 2012, 33, 12-21. [CrossRef]

108. Leonardi, P.M. Materializing Strategy: The Blurry Line between Strategy Formulation and Strategy Implementation. Br. J. Manag. 2015, 26, S17-S21. [CrossRef]

109. Higgins, J.M. The Eight 'S's of successful strategy execution. J. Chang. Manag. 2005, 5, 3-13. [CrossRef]

110. Desroches, D.; Hatch, T.; Lawson, R. Are $90 \%$ of organisations still failing to execute on strategy? J. Corp. Account. Financ. 2014, 25, 61-67. [CrossRef]

111. Rapert, M.I.; Velliquette, A.; Garretson, J.A. The strategic implementation process: Evoking strategic consensus through communication. J. Bus. Res. 2002, 55, 301-310. [CrossRef]

112. Bonoma, V.L.; Crittenden, V.T. “Managing marketing implementation. MIT Sloan Manag. Rev. 1988, $29,7-14$.

113. Thompson, A.J.I., Jr.; Gamble, A.A.; Strickland, E.E. Strategy Winning in the Market Place, 2th ed.; McGraw-Hill: Brazil, 2006.

114. Elkington, J. Enter the triple bottom line. In The Triple Bottom Line: Does It All Add Up; Routledge: Abingdon, UK, 2004; Chapter 1; Volume 11, pp. 1-16.

115. Klettner, A.; Clarke, T.; Boersma, M. The Governance of Corporate Sustainability: Empirical Insights into the Development, Leadership and Implementation of Responsible Business Strategy. J. Bus. Ethics 2014, 122, 145-165. [CrossRef]

116. Conference Board. 1999. Available online: https://www.conference-board.org/topics/publicationdetail.cfm (accessed on 22 June 2018).

117. Baumgartner, R.J. Organizational culture and leadership: Preconditions for the development of sustainable corporation. Sustain. Dev. 2009, 17, 102-113. [CrossRef]

118. Epstein, M.J.; Buhovac, A.R.; Yuthas, K. Implementing sustainability: The role of leadership and organizational culture. Strateg. Financ. 2010, 91, 41-47.

119. Etzion, D. Research on Organisations and the Natural Environment, 1992-Present: A Review. J. Manag. 2007, 33, 637-664.

120. Aguinis, H.; Glavas, A. LLIT 65 What We Know and Don't Know About Corporate Social Responsibility: A Review and Research Agenda. J. Manag. 2012, 38, 932-968.

121. Dentchev, N.A. Corporate social performance as a business strategy. J. Bus. Ethics 2004, 55, 395-410. [CrossRef]

122. Lankoski, L. Corporate responsibility activities and economic performance: A theory of why and how they are connected. Bus. Strategy Environ. 2008, 17, 536-547. [CrossRef]

123. Porter, M. How Competitive Forces Shape Strategy. Harv. Bus. Rev. 1979, 57, 137-145.

124. Porter, M.E. Competitive Strategy: Techniques for Analyzing Industries and Competitors. Compet. Strateg. 1980, 1, 396. 
125. ISO 26OOO SOCIAL RESPONSABILITY. 2010. Available online: www.iso.org/iso/home/standards/iso26000 (accessed on 23 June 2018).

126. Baumgartner, R.J. Modell, Strategien und Management Instrumente; Rainer Hampp Verlag: Munique, Germany, 2010.

127. Hahn, T.; Pinkse, J.; Preuss, L.; Figge, F. Tensions in Corporate Sustainability: Towards an Integrative Framework. J. Bus. Ethics 2014, 127, 297-319. [CrossRef]

128. Nickell, E.B.; Roberts, R.W. The public interest imperative in corporate sustainability reporting research. Account. Public Interest 2014, 14, 79-86. [CrossRef]

129. Klovienè, L.; Speziale, M.T. Sustainability Reporting as a Challenge for Performance Measurement: Literature Review. Econ. Bus. 2015, 26, 44. [CrossRef]

130. Ballou, B.; Casey, R.J.; Grenier, J.H.; Heitger, D.L. Exploring the strategic integration of sustainability initiatives: Opportunities for accounting research. Account. Horiz. 2012, 26, 265-288. [CrossRef]

131. Hahn, R.; Lülfs, R. Legitimizing Negative Aspects in GRI-Oriented Sustainability Reporting: A Qualitative Analysis of Corporate Disclosure Strategies. J. Bus. Ethics 2014, 123, 401-420. [CrossRef]

132. Lampikoski, T.; Möller, K.; Westerlund, M.; Rajala, R.; Möller, K. Green Innovation Games: Value-creation strategies for corporate sustainability. Calif. Manag. Rev. 2014, 57, 88-116. [CrossRef]

133. Alshehhi, A.; Nobanee, H.; Khare, N. The impact of sustainability practices on corporate financial performance: Literature trends and future research potential. Sustainability 2018, 10, 494. [CrossRef]

134. Ramos-González, M.D.; Rubio-Andrés, M.; Sastre-Castillo, M.Á. Building corporate reputation through sustainable entrepreneurship: The mediating effect of ethical behavior. Sustainability 2017, 9, 1663. [CrossRef]

135. Moldavska, A. Defining organizational context for Corporate Sustainability Assessment: Cross-disciplinary approach. Sustainability 2017, 9, 1663. [CrossRef]

136. Caputo, F.; Veltri, S.; Venturelli, A. Sustainability strategy and management control systems in family firms. Evidence from a case study. Sustainability 2017, 9, 977. [CrossRef]

137. Garstecki, D.; Kowalczyk, M.; Kwiecinska, K. CSR practices in Polish and Spanish stock listed companies: A comparative analysis. Sustainability 2019, 11, 1054.

(C) 2019 by the authors. Licensee MDPI, Basel, Switzerland. This article is an open access article distributed under the terms and conditions of the Creative Commons Attribution (CC BY) license (http://creativecommons.org/licenses/by/4.0/). 